\title{
Improvement of STEM Education: Experiential Learning is the Key
}

\author{
Malinda Wilson Gilmore* \\ Assistant Professor, Department of Chemistry, Alabama Agricultural and Mechanical University, USA
}

STEM is a vital area of national interest and concern. STEM education will determine whether the United States will remain a leader among nations and whether we will be able to solve immense challenges in such areas as energy, health, environmental protection, and national security [1]. If the United States of America truly remains focused on broadening the participation of persons in STEM then we will see a generation of scientists, technologists, engineers and mathematicians who will create the new ideas, new products, and entirely new industries in the $21^{\text {st }}$ century [1].

Recently, there has been a gradual decline in the number of Bachelor of Science (BS) graduates from the United States' higher education institutions in the STEM fields [2]. The National Assessment of Educational Progress (NAEP) reported that our nation's education report card shows that fewer than forty percent of our students, at every grade level tested, are proficient in mathematics and science [3]. The Program of International Student Achievement (PISA), an international education benchmark conducted in 2009 by the Organization for Economic Co-operation and Development (OECD), found that our nation did barely average in reading and science, and our nation ranked $25^{\text {th }}$ out of thirty four other nations in mathematics [4]. These findings are indicators that our nation is in need of improvement in STEM education

Numerous studies and national reports (i.e., Science for All America, Rising above the Gathering Storm, National Action Plan for Addressing the Critical Needs of the U.S. Science, Technology, Engineering and Mathematics Education System) have addressed concern and brought attention to the need for improvement in STEM education [5-7]. The National Science Foundation firmly believes that to ensure long-term prosperity for our nation, we must renew our collective commitment to excellence in education and the development of scientific talent [8].

The report, Greater Expectations: A New Vision for Learning as a Nation Goes to College (2002), calls for major changes in undergraduate education that will guarantee all students aspiring to attend college cannot only go to college but also receive an education that has a lasting value [9]. It further advocates that learning paths must be outlined in order to meet the challenges of the workforce and global connectedness [9]. In order to improve STEM education, individuals must know how to create and discover and what better way to gain the knowledge than through experiential learning. Experiential learning will improve STEM education and better enhance and strengthen or nation, and raise the standards of solving, not only our nation's problems, but world's problems.It is imperative that we take action now.

VA Shiva Ayyadura, the inventor of the E-mail system, stated that "Students need to be gaining hands-on experiences, getting their hands dirty, working on things and developing things in order to truly gain an understanding and appreciation for STEM. Colleges need to modify curriculums to make sure that students experience experiential learning versus just sitting in a classroom and learning theory." [10]. Experiential Learning is the process of making meaning from direct experiences [11]. Direct experiences include hands-on projects in which students are able to apply science, technology, engineering and mathematical skills to real life situations. Students are learning beyond core subjects when engaged in hands-on STEM experiential learning.

Improvement in STEM education will require educators and students to think more critically and analytically while truly engaged in experiential learning activities. Teachers must let go of the conventional style of teaching. Students can't afford to sit and do worksheets all day. Students in STEM disciplines need to be able to approach problems hands-on with finding solutions in mind. The great astronomer and skeptic, Carl Sagan said, "Extraordinary claims require extraordinary evidence." Students must be curious about the world around them. STEM education must encourage curiosity and actively engage students while modeling higher level thinking skills in search for evidence to help solve problems.

As previously stated, STEM education will determine whether the United States will remain a leader among nations. The United States of America is constantly creating new jobs in STEM related fields and will need people with undergraduate and advanced degrees to fill these positions. If we don't focus on a plan to improve STEM education, we will fall short. Improvement in STEM education is vital to our nation if our students are to have a future of success in science, technology, engineering, and mathematics. We must do what we need to do for improvements in the STEM fields. We must make it relevant to the students. We must put our nation back on top in science, technology, engineering, and mathematics. The key to the improvement of STEM Education is indeed experiential learning.

\section{References}

1. President's Council of Advisors on Science and Technology (2010) Report to the President. Prepare and Inspire: K-12 Education in Science, Technology, Engineering, and Math (STEM) for America's Future. Executive Office of the President.

2. American Association of State Colleges and Universities (2005) Strengthening the Science and Mathematics pipeline for a Better America. Volume 2, Number 11.

3. National Center for Education Statistics (2012) The Nation's Report Card Science 2011. Institute of Education Sciences, Department of Education, Washington, DC

4. Fleischman HL, Hopstock PJ, Pelczar MP, Shelley BE (2010) Highlights from PISA 2009: Performance of U.S. 15-Year-Old Students in Reading, Mathematics, and Science Literacy in an International Context.

5. American Association for the Advancement of Science (AAAS) (1990) Project 2061: Science for all Americans, Oxford University Press, New York, USA.

6. (2008) Rising above the Gathering Storm: Energizing and Employing America for a Brighter Economic Future. The National Academies Press, Washington, DC, USA.

7. National Science Board (2007) National Action Plan for Addressing the Critical Needs of the U.S. Science, Technology, Engineering and Mathematics Education System. National Science Foundation, Arlington, VA, USA.

8. National Science Foundation (2010) Preparing the Next Generation of STEM Innovators: Identifying and developing our Nation's Human Capital.

9. National Panel Report (2002) Greater Expectations: A New Vision for Learning as a Nation Goes to College. Association of American Colleges and Universities.

10. VA Shiva Ayyadurai's path to the Smithsonian. The Washington Post 2012

11. Mughal F, Zafar A (2011) Experiential Learning from a Constructivist Perspective: Reconceptualizing the Kolbian Cycle. International Journal of Learning and Development 1: 1-11.

*Corresponding author: Malinda Wilson Gilmore, Department of Physics, Chemistry and Mathematics, Alabama Agricultural and Mechanical University, 4900 Meridian Street, Normal, Alabama 35762, USA, Tel: 256-372-4803; Fax: 256-372-8288; E-mail: malinda.gilmore@aamu.edu

Received March 26, 2013; Accepted May 02, 2013; Published May 06, 2013

Citation: Gilmore MW (2013) Improvement of STEM Education: Experientia Learning is the Key. Mod Chem appl 1: e109. doi:10.4172/2329-6798.1000e109

Copyright: @ 2013 Gilmore MW. This is an open-access article distributed under the terms of the Creative Commons Attribution License, which permits unrestricted use, distribution, and reproduction in any medium, provided the original author and source are credited. 